Western University

Scholarship@Western

Law Publications

Law School

$5-27-2001$

Beyond Librarianship: Are Librarians Becoming Isolated in the New Information Age?

Margaret Ann Wilkinson

Western University, mawilk@uwo.ca

Roma Harris

Follow this and additional works at: https://ir.lib.uwo.ca/lawpub

Part of the Law Commons

Citation of this paper:

Wilkinson, Margaret Ann and Harris, Roma, "Beyond Librarianship: Are Librarians Becoming Isolated in the New Information Age?" (2001). Law Publications. 79.

https://ir.lib.uwo.ca/lawpub/79 


\section{Beyond Librarianship: Are Librarians Becoming Isolated in the New Information Age?}

\author{
Margaret Ann Wilkinson \\ Faculty of Information and Media Studies \\ University of Western Ontario \\ mawilk@uwo.ca
}

\author{
Roma Harris ${ }^{1}$ \\ Faculty of Information and Media Studies \\ University of Western Ontario \\ harris@uwo.ca
}

\section{ABSTRACT}

This paper continues a series exploring the perceptions of entering university students about the roles of librarians and others. A model developed by Elizabeth Graddy, suggesting that the extent to which an occupation receives legal sanction reflects the public's perception of its social relevance, is tested. While Graddy's focus on the relationships between occupations and the public, rather on conditions within various professions, is reinforced as predicting an occupation's ability to meet the challenges of a changing society, the data from this study demonstrate more predictive variables than those identified by Graddy. A more complex view of the future of librarianship is emerging.

\section{RÉSUMÉ}

Cette communication continue une série qui explore les perceptions des étudiant-e-s de l'université de première année pour ce qui est des rôles des bibliothècaires et des autres. Un modèle dévéloppé par Elizabeth Graddy qui suggère dans quelle mesure une occupation reçoit de la sanction légale médite sur la perception publique de sa pertinence sociale, est mise à l'essai. Pendant que le point de mire de Graddy sur les relations entre les occupations et la publique, plutôt que les conditions à l'intérieur des professions variées, est renforcé comme une prédiction de l'abilité de l'occupation d'essuyer des défis de la société variable, les données de cette étude démontrent les variables plus prophétiques que celles qui sont identifiées par Graddy. Une vue plus complexe de l'avenir de la bibliothéconomie est émergente.

One of the themes to be explored in this conference includes the claim that "conventional libraries are integrated into information architectures." There is clear evidence that librarianship and library science have much to contribute to the emerging practices and theoretical enquiries involving concepts like knowledge management (Davenport and Cronin 2000). Indeed, one would expect librarians and their institutions to thrive in the emerging information society where, it has been said, the value of knowledge workers is increasingly being recognized (Lavoie and Roy 1998) since the quintessence of librarianship is its character as a classic information sector occupation -- and its practitioners have long been identified as knowledge workers. On the other hand, the continuing participation of libraries and librarians in these developments needs to be questioned when important work from other fields discussing the new information environment make no reference to either library science literature or librarians (as examples: Tapscott et al 2000; Thorp et al1998). Moreover, the authors have already

\footnotetext{
${ }^{1}$ The authors are grateful to the Social Sciences and Humanities Research Council of Canada for its generous support (grant no. 410-95-0185).
} 
reported elsewhere on evidence emerging from their current research that indicates the public may increasingly view librarians as isolated from, rather than integrated into, the emerging dominant information culture (Harris and Wilkinson 2000; Harris and Wilkinson 2001).

This paper continues the authors' exploration of the responses of 2,047 entering university students in a study of "Career opportunities: 2000 and beyond". Each student completed one of eight, randomly assigned, different questionnaires. Each instrument explored different aspects of comparisons between twelve different occupations: lawyer, reporter/newscorrespondent, internet researcher, paralegal, animator, systems analyst, librarian, database administrator, announcer/newscaster, physical therapist, computer engineer, and medical records technician. In addition, certain of the questions asked for the students' perceptions of the occupation of mechanical engineer. No fewer than 250 students answered each of the eight questionnaires.

The students responded to questions about the future of each occupation: for example, its status, the education required to enter it, its future earnings potential, and so on. The students' perceptions of librarianship were generally less than flattering. As indicated in TABLE 1, of all twelve occupations surveyed in this part of the study, the students thought librarianship was the only one shrinking, whereas in fact, although this was consistent with the Ontario government projections for librarianship, the federal projections were more optimistic (predicting a steady state). On the other hand, the federal government has forecasted a shrinking market for reporters, animators, announcers and medical records technicians, and, in each case, the student predictions mirrored the more optimistic Ontario forecasts (Ontario Job Futures 1999; Canada Job Futures 1999 ). Similarly, librarianship was the only career where the students actually underestimated the starting salaries reported in Canada. The students anticipated the lowest starting salaries for librarians amongst all twelve occupations, whereas in fact, entering librarians' actual starting salaries in Canada are only topped by those of lawyers (Harris and Wilkinson 2000, Table 4; Harris and Wilkinson 2001, Table 5).

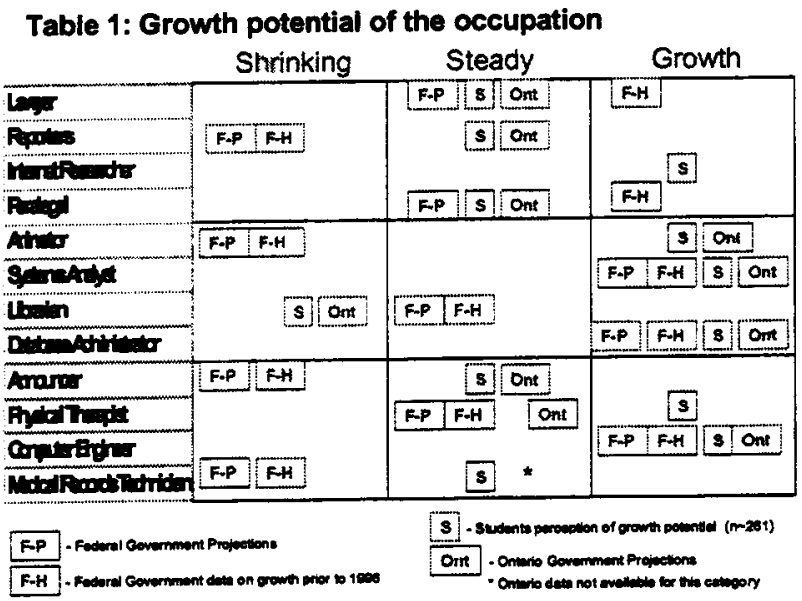


As discussed elsewhere, the students' generally low opinions of librarianship were further evidenced when they assigned their lowest prestige rating to librarian. Their highest went to lawyer and computer engineer, followed by physical therapist (Harris and Wilkinson 2000, Table 1; Harris and Wilkinson 2001, Table 1). Indeed, the largest proportion of the students believed that librarians required no university prepartion but rather, along with announcers/newscasters, internet researchers, and animators, only a community college diploma. As discussed elsewhere, this was the one occupational instance in which the students vastly underestimated the actual educational requirements for entry. In the other eleven cases, they were either accurate in reporting or tended to overestimate (for reporters and systems analysts) the educational preparation required (Harris and Wilkinson 2000, Table 2; Harris and Wilkinson 2001, Table 2).

The students perceived librarianship to be the most female dominated of the twelve occupations. They thought that physical therapist was the second most female dominated of the twelve occupations they were examining (librarians at $80 \%$ women, physcial therapists at $60 \%$ ). In fact, although librarianship in Canada is very highly female dominated, medical records technician actually tops the federal list of women entering the occupations - at $99 \%$ women Canada-wide, followed by physical therapists at $82 \%$ and then librarians third, at $76 \%$ (see $\boldsymbol{T A B L E} 2$ ).

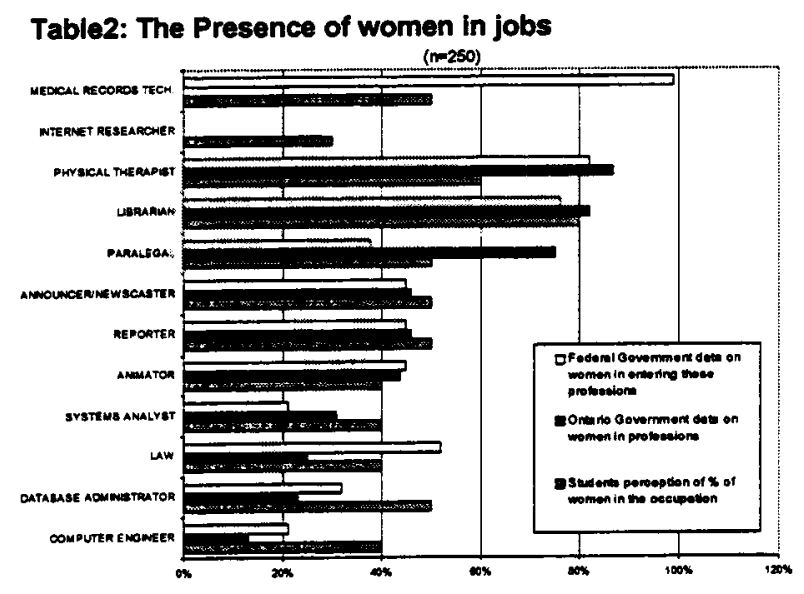

Although the students' perceptions of an occupation's status tended to be inversely related to their perceptions of the number of women in the field, they were not consistent in this and did indicate that they thought overwhelming that female-dominated physical therapy was a profession with high status (very closely trailing lawyers and computer engineers, which they accurately perceived to be male dominated).

It might be tempting to attribute the generally low rankings accorded to librarians by the students in this study to the female-dominated nature of the field. On the other hand, as may be seen in TABLE 2, the federal government data on the number of women entering law is rapidly outstripping the percentage of women in the Ontario legal profession. Indeed, studied in terms of gender distribution, law is the most rapidly 
changing occupation. ${ }^{2}$ If the attribution of the relationship between female-domination and the low rankings for librarianship in this study was accurate, it would certainly point logically to a future inevitable decline in the prestige of law as that profession increasingly embraces women. Indeed, Bryna Bogoch has already documented the fact that the reactions in Israeli courtrooms to female judges and lawyers are markedly different and inferior to the courtrooms reactions to male judges and lawyers (Bogoch 1999). However, in this study, law, which, even at present, is less male dominated than computer engineering or systems analysis, appeared at the pinacle of the students' estimation (Harris and Wilkinson 2000 and Harris and Wilkinson 2001). Moreover, an explanation based entirely on gender composition does not seem entirely adequate for the present study in light of the students' more favourable perceptions of physical therapy, for example, which is also in fact heavily female dominated.

This paper will therefore explore further possible explanations for the students' attitudes toward librarianship. The investigation will begin from an apparent anomaly in the data from our study. As previously noted, although the students accorded librarianship their lowest prestige rating, almost $2 / 3(62 \%)$ thought it was a profession, more than considered "internet researcher" to be a profession (Harris and Wilkinson 2001).

The debate about professionalism, which is not new in library and information science by any means (Harris 1992, 1), continues to have relevance because, as Kelly points out,

[t] he words [profession, professional, professionalism - the professional family of words] have an almost incantatory function, combined with the special utility of so many meanings that listeners or readers can take what they want from them, ranging roughly from concepts of business acumen to high moral principle to proficiency and lofty standards of quality. And they have one other quality that is invaluable: favourable resonance. In whatever mode of meaning, they generate agreeable vibrations or responses from the reader or listener. (Kelly 1994, 9)

Since those laying claim to professional status, including librarians, have always depended upon their identification with a unique body of knowledge (Johnson 1972), all professionals are knowledge workers. The value of knowledge workers is increasingly being recognized in society (Lavoie and Roy 1998). It should follow that those occupations showing greater degrees of professionalism (whatever definition of professionalism is invoked, see Tancred 1999 or Kelly 2000) should be increasingly valued in society.

\footnotetext{
${ }^{2}$ Mechanical engineering, which is discussed later in this paper, and was not discussed in the earlier papers from this research (Harris and Wilkinson 2000 or Harris and Wilkinson 2001), currently attracts women to fill only $14.7 \%$ of student openings (Hamilton 2001 ). Women comprised only $8.3 \%$ of the annual salary survey respondents of engineers in Ontario (2000 PEO Membership Salary Survey).
} 
One of the classic claims to professional status is obviously "the profession's own definition of its membership which acknowledges that a profession, if fully developed, has the legal right to control those who enter and are acknowledged as professionals" (Tancred 1999, 36, emphasis in original). Of the professions in this study for whom results have already mentioned, the lawyer and physical are legally self-regulating in Ontario (respectively by the Law Society of Upper Canada Act and the Regulated Health Professions Act). For some parts of this study, data was gathered from the students about their attitudes toward a thirteenth occupation, that of mechanical engineer. This profession is also legally self-regulating in Ontario (under the Professional Engineers $A c t)$. On the other hand, journalist or reporters and librarians in Ontario, as in the rest of Canada, are subject only to laws of general application and are not specifically occupationally regulated. The occupation of "internet researcher" was first encountered by the authors on the website of Syracuse University's School of Information Studies in 1999. It has no counterpart in Canadian federal job classifications or Ontario government data. Throughout this study, where elaboration was given of "internet researcher" in the survey instruments administered to the students, exactly the same characteristics and descriptions were given for internet researcher as for librarian.

As mentioned earlier, and reported elsewhere (Harris and Wilkinson 2000 and Harris and Wilkinson 2001), lawyers and physical therapists were both seen by virtually all the students (98\%) as being professionals, although proportion of women practitioners of physical therapy in Ontario is higher than the proportion of women practicing in any other field studied (87\%) - and certainly higher than in law $(25 \%)$. The percentage of students viewing the occupation of reporter/news correspondent as a profession was about mid-range among the twelve occupations in this part of the study (76\%), with librarianship at $62 \%$ and internet researcher well at the bottom (at 50\%) (see $T A \boldsymbol{B} L \boldsymbol{E} 3$ ).

Table 3: Professionalism and prestige

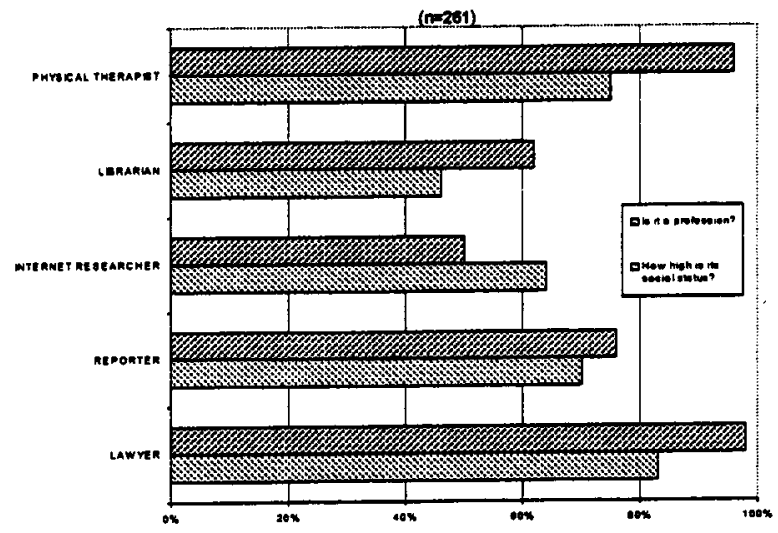


In 1991, Elizabeth Graddy examined the increasing American state regulation of geologists, landscape architects, physician assistants, psychologists and librarians between 1968 and 1980. She argued that

[i]nformation asymmetry exists between most service providers and consumers. Whether it is of sufficient importance to generate market failure depends on the information search costs for consumers and the consequences of error in the selection of providers. In occupations with high search costs, i.e., those with large variation in service quality, most skill required to evaluate the service, and little contact between consumers and practitioners, consumers may be unable to determine the level or quality of services needed, resulting in an oversupply of high- or low-quality services ... for occupations in which information asymmetry is severe and has important consequences, intervention [through legal regulation] is justified. The appropriate regulation depends on the ability of consumers to evaluate the service with information and the consequences of error in that evaluation. (Graddy 1991, 678)

She made three findings which appear to have demonstrated to her satisfaction why she had found that librarians had the least increase in state regulation during the period of her study: (1) librarians (as well as geologists and physician assistants) "are hired almost exclusively by institutional clients," which, she claimed, "provides an indicator of the likelihood of consumer participation in this political process" of regulating occupations (Graddy 1991, 688); (2) librarians (again like geologists) have no professional competitors - that is, they do not resist a "license" being given to others for services that they already perform, or would like to perform (Graddy 1991, 679); and (3) there is no significant information asymmetry [between librarians and their clients] and thus no consumer or public interest rationale for regulation (Graddy 1991, 685). Graddy does not specifically present evidence to demonstrate her support for the conclusion that there is no significant information asymmetry between librarians and their clients. However, she did develop an elaborate five point index for the seriousness of the impact of her five professions on the public. On this scale, including such elements as the degree of possible harm through personal or property injury, the remediability of any harm caused, and the degree of discretion exercised, Graddy assigned librarians her lowest score: 0 (Graddy 1991, 689) ! This bolsters her conclusion that, of geologists, landscape architects, physican assistants, psychologists and librarians (all of whom had been regulated in some places, at least, in the United States during the period of her study) "[a]rguments for regulating librarians are the least compelling." (Graddy 1991, 685)

Graddy's theory is interesting because she connects the likelihood of occupational regulation with the information relationship between the service provider and the user. Traditional statements of the nature of professionalism, on the other hand, have focussed on the information base held by the "professional," rather than the communication of that information to the users. For example, amongst four sources of claims to professional status identified by Tancred is the following: 
...one could suggest a professional definition which would include all those with the relevant level of tertiary education, even if they have never been members of a professional association. (Tancred 1999, 37, emphasis in the original) ${ }^{3}$

Purely focussing on the body of specialized knowledge held by the occupation, however, has not proven to be reliably useful in discriminating between those groups traditionally accorded professional status and those less commonly recognized as professions (Harris 1992,5 ff.). Indeed, in this study, while over half the students accorded librarianship professional status, they also widely underestimated the educational preparation required, as noted above. Graddy's argument leads to the hypothesis that the information asymmetry between the public and the occupation can predict the social value placed on that occupation.

In Graddy's terms, occupations perceived to have high search costs, and therefore, most claim to high social value, will be those perceived by the public to require the most skill to evaluate the service and to have largest variation in service quality. One of the questions in this study asked the students to compare two descriptions of five different occupations, in each case one narrower and one broader. The results are shown in TABLE 4. In the case of the lawyer, over $50 \%$ of the students chose the wider description of the occupation as the best, endorsing a view of the lawyer as counsellor rather than simply "hired gun" (see also Wilkinson et al 1996). Similarly, over half the students chose the wider view of the physical therapist, as an independent health professional rather than as one member of a health team under the direction of a doctor.

Table 4: Definition of the occupation

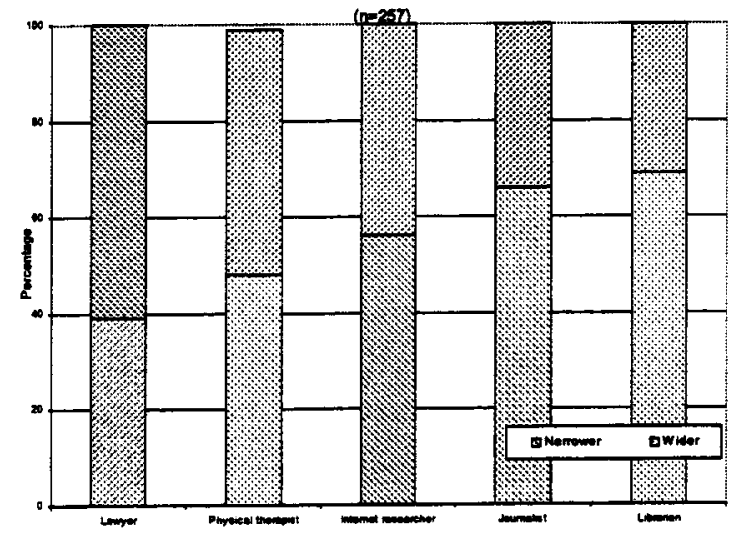

While more students chose the wider description of both internet researcher and journalist than chose the wider description for librarians, in each of these latter three

\footnotetext{
${ }^{3}$ Tancred's empirical work explores the roles of architects, engineers, and bankers. She ultimately prefers yet another definition as being the most inclusive of women: the State, through its official statistics, formulates a definition of all professions.
} 
cases, over half the students selected the narrower description of the occupation, the one without any element of judgement (see $A P P E N D I X A$ ). The fact that by far the largest proportion of students chose the wider description of law and then nearly the same proportion chose the wider description of physical therapy mirrors the first and second place dominance of these two occupations in terms of the students perceptions of professionalism and social status (see again $T A B L E$ 3). It also parallels the division between these two occupations as self-governing in Ontario and the other three occupations listed. Of these latter three, however, reporters fared better than librarians in the students' perceptions of the breadth of the profession, as well as in terms of professionalism and social status. On the other hand, the internet researcher occupation was given a wider ambit of activity by more students than either journalists or librarians, though still under half, while it was perceived least often as a profession and had a lower social status than reporters. This latter is particularly interesting because the occupational descriptions given for the internet researcher and the librarian were exactly functionally equivalent (see Appendix A). Using the data from Table 4, TABLE 5 graphically illustrates the differences in the students' perceptions of the roles of librarians and internet researchers, given these two identical choices.

Table 5: Students' views of the different ambits of librarianship and "internet researcher" (from table 4)

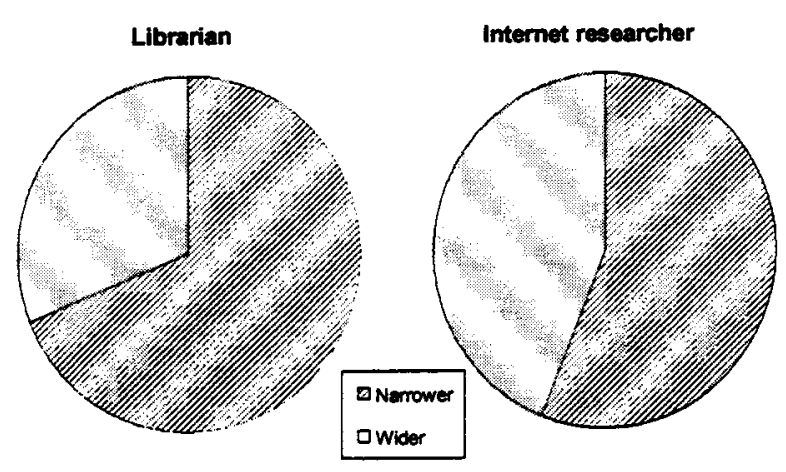

Thus Graddy's concept that those perceived to require the most skill in evaluation will claim a greater share of public's regard seems to be born out in this study in terms of the students' views of the judgement required to practice each calling, at least to the extent that the students clearly awarded both status and professional recognition to those occupations which they most viewed as requiring judgement.

Graddy appears, further, to identify the level of contact between consumers and practitioners as a variable which can potentially be used to discriminate between occupations with high social value and those with lower value. In this study, one of the instruments asked the students a series of questions about the types of skills they thought were required in each of the six occupations of lawyer, physical therapist, mechanical engineer, reporter, librarian and internet researcher. The following skills were canvassed for all six: nurturing and reassuring communication, compassion and empathy, rapport 

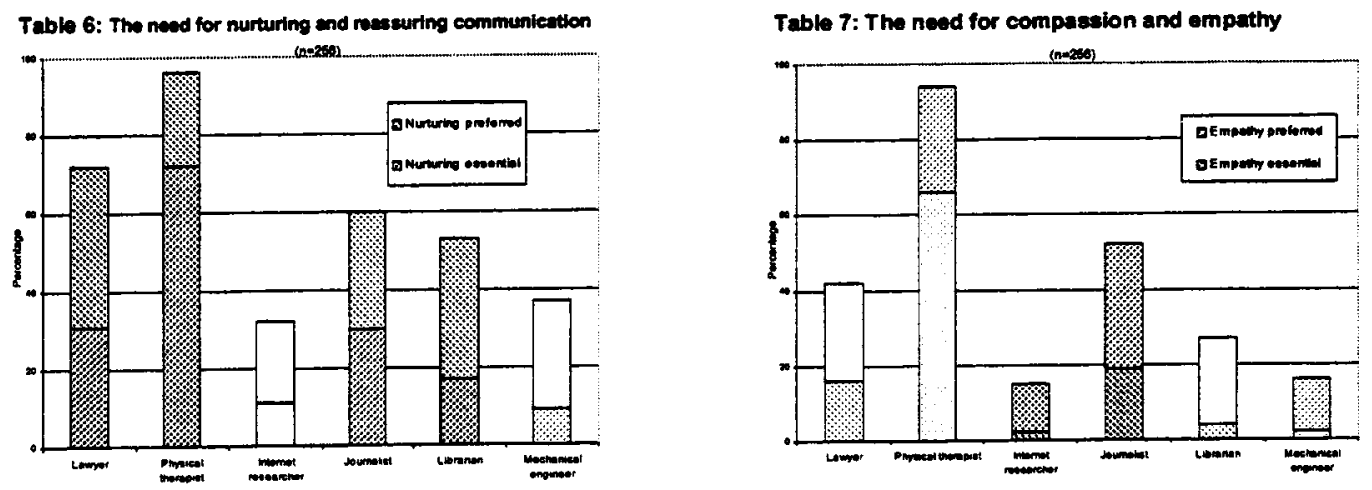

Table 8: The need for rapport and trust building

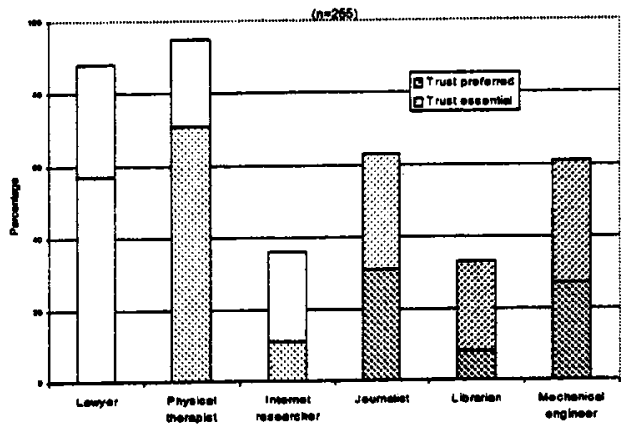

Table 9: The need for persuading

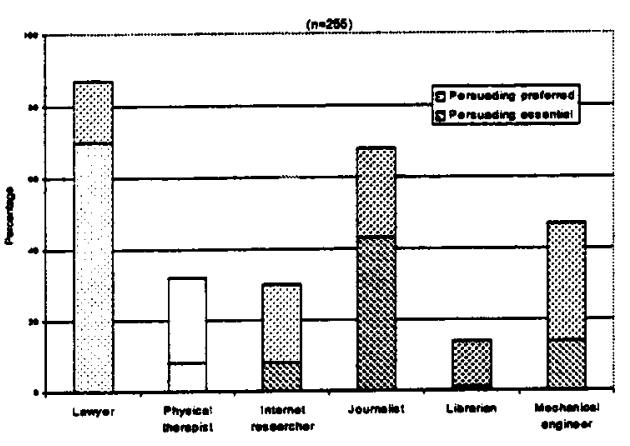

Table 10: The need for mediating
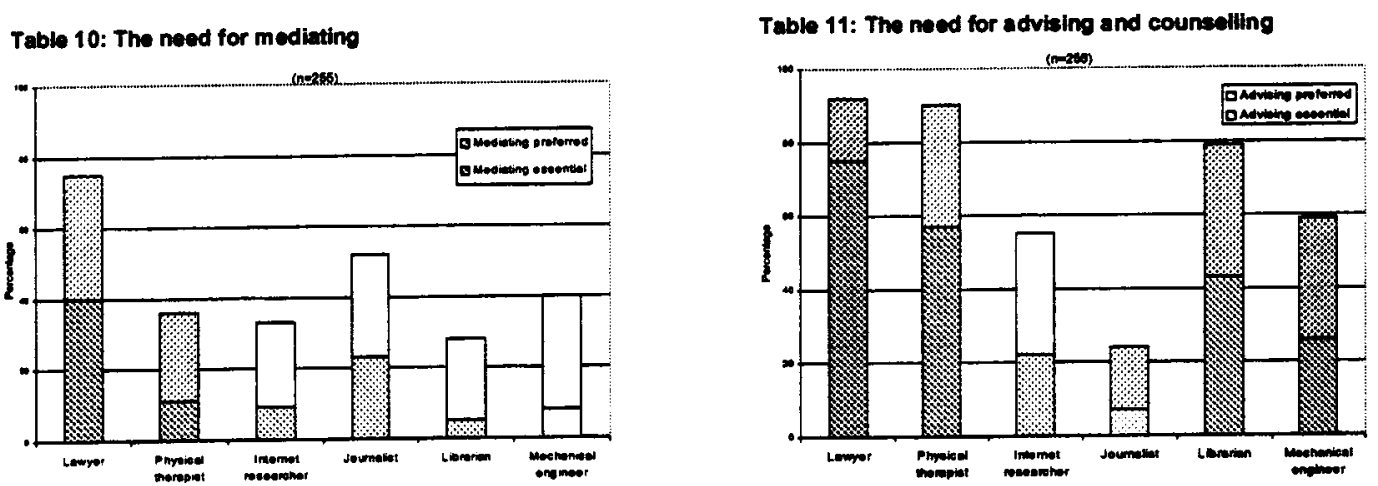

and trust building, persuading, mediating and, finally, advising and counselling. In each case, the students were given the choice of selecting the skill as absolutely essential, preferred, helpful if present, unnecessary or "detracts from practice if present". TABLES 6-11 show the percentage of students identifying each of these skills as either essential or preferred for each of the six occupations. It is striking that although almost all the students found compassion and empathy to be prime skills for physical therapy (TABLE 7), that skill is not identified uniformly with all those occupations which the students saw most strongly as professions or worthy of high social status (TABLE 3). Conversely, the 
skills of persuading and mediating, while highly valued in lawyers by the students, were not thought particularly necessary to the highly regarded practice of physical therapy (TABLES 3, 9 and 10). TABLE 11 indicates that the skill of advising and counselling was viewed by the students as a prime requirement, not only for the highly respected occupations of physical therapy and law, but also for librarianship, less so for internet researchers and only by a few for journalism. The students' perceptions of the necessity of nurturing and reassuring communication in each of the occupations mirrors their views of the level of professionalism involved in the occupation, except that considerably more skill in nurturning is perceived to be required for physical therapists than lawyers (TABLE 6). On the other hand, TABLE 8, showing the level of skill in rapport and trust building required in each occupation, more or less exactly mirrors the students' perceptions of the social status to be accorded to each occupation: physical therapy and law quite exceed the other occupations the level of trust building required, as they do in occupational prestige (although physical therapy is highest in the former and law in the latter); reporters lie in the middle; internet researchers and librarians bring up the rear, although in both cases, internet researcher edges ahead of librarian. It therefore seems that the public's perception of the need for rapport and trust with the public in an occupation may be most closely linked to the public's perception of the occupation's professionalism and public status, which seems consistent with Graddy's thesis (although perhaps an even better indicator than those which she proposed).

Graddy, as discussed, also argues that the fact that librarians (and geologists and physicians' assistants) are hired by institutional clients rather than individuals makes then less likely to be highly valued in a democratic society. In this study, the students perceived librarians to be far, far more often employed in the government sector $(61 \%)$ than they did any of those working in the other eleven occupations (the next nearest was the mean percentage of medical records technicians thought to be employed in the public sector, 51.58\%) (Harris and Wilkinson 2001). The authors have argued elsewhere that this perception of librarianship as being primarily located in the public sector may be responsible, at least in part, for the low estimation in which librarianship seemed to have been held by the students participating in the study (Harris and Wilkinson 2001). The data would equally be consistent with Graddy's notion (see TABLE 12).
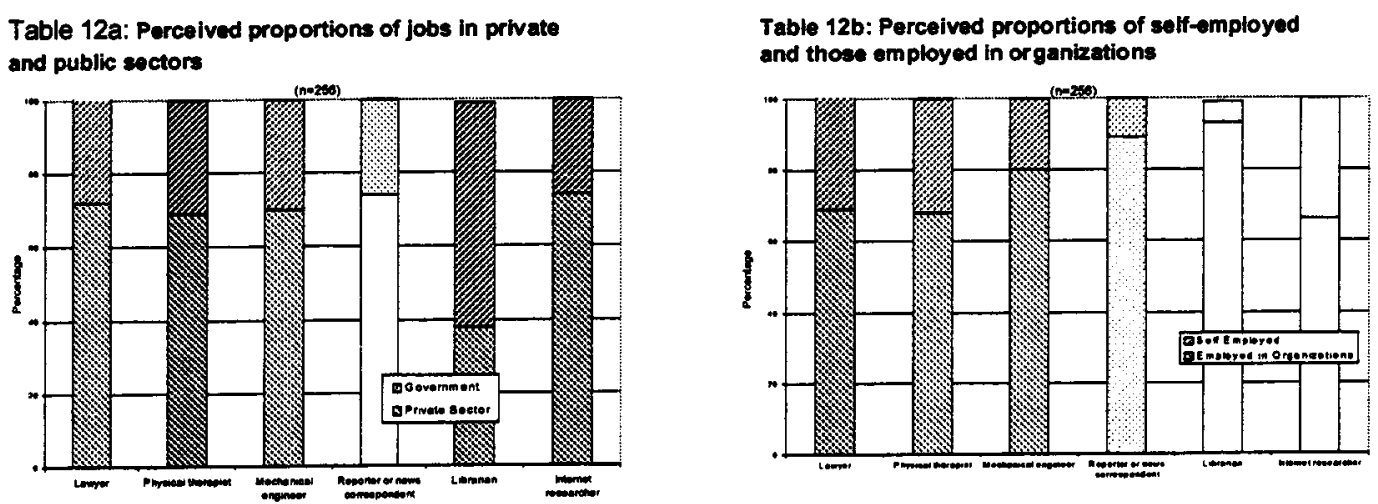
Neither analysis, however, can explain adequately why internet researchers, although perceived by the students to be less government centred and more institutionally employed, are none-the-less perceived as less professional than librarians (TABLE 3). Moreover, while it may be the case that landscape architects and psychologists are hired by individuals (as Graddy claimed), this factor as a distinguishing one predicting government regulation of occupations and, related to this, their social importance, would seem to be challenged by the cases of both professional engineers and lawyers. As David Williams recounts

[t] he decade of the 1940's was a much a watershed for the legal profession as it was for every other aspect of Canadian society. Before 1939, the

Depression had laid a heavy hand on commercial activity, such as it was, and Canada was still undergoing the transition from an essentially agrarian economy to an industrial one. ... Government regulation... has [since] steadily become more entrenched. For lawyers, the change was profound. ... law firms grouped themselves into specialized pens - the real estate section, the trust section, the securities group .... (Williams 1995,5 )

The most recent data available from the self-governing association of Professional Engineers Ontario indicates that probably fewer than $10 \%$ of Ontario's professional engineers are self-employed (2000 PEO Membership Salary Survey: Detailed Report, 11).

On the other hand,

[1] ibrarians have traditionally cast the public sector/ private sector debate as one concerning where the cost of service delivery will fall.

Librarians who have seen the information paradigm as the best guide to the future... have been aggressively suggesting that in the new age "information brokers" or "free lance librarians" will earn their livelihood by selling information to the highest bidder... many, perhaps most, members of the library profession have seen it in quite different terms... that librarians must resist (or at least cautiously approach) the commodification of information. (Harris et al 1998, 44)

If, however, at least in so far as the prestige to be according information occupations is concerned, there is the beginnings of an explanation in Graddy's notion that it is the difference between self-employment and institutional employment which matters, rather than the difference between public and private sector employment, then perhaps the question of the commodification of information may be an irrelevant debate in librarianship.

Perhaps Graddy's notion is better expressed in terms of the level of managerial activity people in various occupations are perceived to have, rather than in terms of the nature of their employment. One of the questions in this study asked the students the extent to which they believed people in various occupations managed other staff. As can 
be seen in $T A B L E$ 13, the pattern of the students' responses to this question (rather than the pattern of their responses to the questions involving locus of employment discussed above) exactly mirrors the extent to which they perceived the various occupations as professions in $T A B L E 3$.

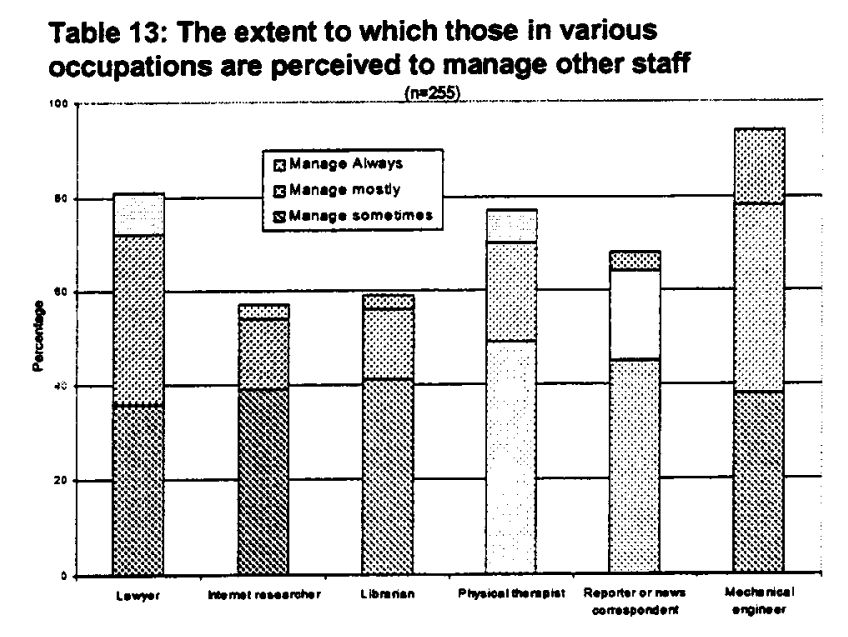

One possible reason for students' perception of the issue of professionalism as separate from the question of social status brings this paper back full circle to the contradiction between librarianship's view of its own potential and the apparent lack of recognition of this outside the occupation itself. It is true that there are internal challenges to be faced within librarianship. Harris, Hannah and Harris identify the public/private sector debate as key: " the most intensely contested aspect of the post-industrial metaphor as understood by librarians" (Harris et al 1998, 44). However, other occupations, such as law, face equally daunting internal issues:

Two different reactions or stories, one accepting, one critical, have emerged as explanations of these changes in the contemporary legal profession. ...[One] story is of a profession being renovated and improved, ... A different, more critical account of changes in the legal profession is a story told with some emotion about a decline in values ...

These two stories or reactions are deeply contradictory accounts of the legal profession. They share common ground in two respects. First they agree that the legal profession is undergoing rapid transformation... Second both stories claim to be about professional values. (Kelly 1994, 2-3)

TABLE 14 illustrates, for the six occupations discussed in this paper, the students' responses when asked whether each of the thirteen occupations in the study were involved in the "production, distribution, or manipulation of information." Perhaps the most important observation in the table is that the students were most divided over the role of the librarian - about equal numbers saying librarians were slightly and heavily involved - and only a few fewer saying exclusively. By contrast, over three quarters of 
the students were sure physiotherapists had either no role or only a slight one, while almost the same proportions were sure lawyers had an exclusive or heavy role. More students were more sure that both reporters and internet researchers had a heavy or exclusive involvement in these information processes than were sure that librarians had those roles. While many students were willing to accord librarians professional status, they are unclear what the role of the librarian is - and therefore accorded librarians less social prestige.

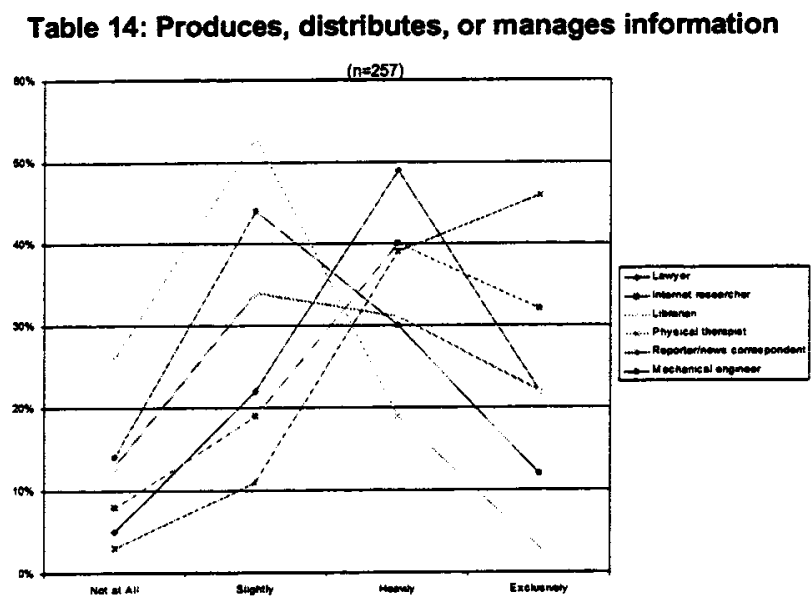

Thus, data from this study indicate that, more important than clarifying competing idiologies and attitudes internally, an outward focus, clear communication of roles, and a deliberate effort to overcome isolation may be the most important keys to occupational survival for librarianship, let alone professional identity, in the future.

\section{APPENDIX A:}

\section{THE PAIRED CHOICES GIVEN STUDENTS FOR BEST DESCRIPTION OF CERTAIN OCCUPATIONS}

The [librarian/internet researcher] answers questions by directing people to sources of information; the [internet researcher/librarian] does not manipulate, analyse or criticize sources of information or evaluate, interpret or apply the information to particular problems.

OR

The [internet researcher/librarian] searches, selects only the best information retrieved, and delivers the results to the person who asked the question.

The lawyer should examine the client's situation and go beyond the question asked by the client, weigh other people's interests as well as the client's, examine both the short and long term implications for the client, and then only act in the best interests of the client, whatever the client's actual instructions are. 
OR

After accepting a person as a client, the lawyer should only give the advice requested and then act to the best of her or his ability exactly as the client directs. The client has the right to expect the lawyer to do everything possible in the client's interest.

The journalist seeks to report on as many events as possible as they happen, striving for objectivity, accuracy and completeness as the news unfolds - without commentary or judgement.

OR

The journalist seeks to select the most important items for a given audience and interpret them to that audience - attempting to influence and enhance the development of social justice and culture.

The physical therapist (physiotherapist) is a health professional who contributes directly to the welfare of her or his own patients and the overall health of a given society.

OR

The physical therapist (physiotherapish) is a member of a health team under the direction of medical doctors and provides particular support to the doctor's patients within the context of an overall course of treatment.

\section{REFERENCES:}

Bogoch, Bryna. 1999. Courtroom Discourse and the Gendered Construction of Professional Identity. Law and Social Inquiry 24(2): 329-375.

Canada. Job Futures: Part 2: Career Outlooks for Graduates. 1999. http://www.hrdcdrhc.gc.ca/JobFutures/english/volume2/

Davenport, Elisabeth and Blaise Cronin. 2000. Knowledge Management: Semantic Drift or Conceptual Shift? Journal of Education for Library and Information Science, 41(4): 294-306.

Graddy, Elizabeth. 1991. Toward a General Theory of Occupational Regulation. Social Science Quarterly 72: 676-695.

Hamilton, Dwight. 2001. Engineering Still a Popular Career Choice, Study Shows. Engineering Dimensions 22 (2): 12.

Harris, Michael, Stan A. Hannah, and Pamela C. Harris. 1998. Into the Future: the Foundations of Library and Information Services in the Post-industrial Era (2 $\left.{ }^{\text {nd }} e d.\right)$. Greenwish, Conn.: Ablex Publishing.

Harris, Roma. 1992. Librarianship: The Erosion of a Woman's Profession. Norwood, N.j.: Ablex. Harris, Roma, and Margaret Ann Wilkinson. 2000 Imaging the Knowledge-based Economy: Soon -to-be labour force entrants predict the future of work. In Manjunath Pendakur and Roma Harris (Eds.), Citizenship and Participation in the Information Age. Government of Canada, Department of Canadian Heritage (forthcoming) [Proceedings from Citizens at the Crossroads Conference, October, 1999 at the University of Western Ontario, London, Ontario.]

Harris, Roma and Margaret Ann Wilkinson. 2001. (Re)Positioning Librarians: young people's views on the information sector. In submission to Library and Information Science Research. [Presented as a 
refereed paper at the Association of Library and Information Science Educators (ALISE) Annual Conference, January 11, 2001 in Washington, D.C.]

Johnson, Terence J. 1972. Professions and Power. London: MacMillan.

Kelly, Michael J. 1994. Lives of Lawyers: Journeys in the Organizations of Practice. Ann Arbor: University of Michigan Press.

Law Society Act, Revised Statutes of Ontario 1990, c.L-8, as amended..

Lavoie, Marie, and Richard Roy. 1998. Employment in the Knowledge-Based Economy: A Growth Accounting Exercise for Canada. R-98-8E, Research Papers Series, Applied Research Branch Strategic Policy, Human Resources Development Canada.

Ontario Job Futures. 1999. http://www.ont.hrdc-drhc.gc.ca/english/lmi/eaid/occ.info/ojf/

Professional Engineers Act, Revised Statutes of Ontario 1990, c.P-28, as amended.

Professional Engineers of Ontario. 2001. 2000 PEO Membership Salary Survey: Detailed Report. http://www.peo.on.ca/EngPractice/Salary_Survey/2000detailed.pdf

Regulated Health Professions Act, Statutes of Ontario 1991, c.18, as amended.

Tancred, Peta. 1999. Outsiders/Insiders: Women and Professional Norms. Canadian Journal of Law and Society 14(1): 31-44.

Tapscott, Don, David Ticoll, and Alex Lowry. 2000. Digital Capital: Harnessing the Power of Business Webs. Boston, Mass.: Harvard Business School Press.

Thorp, John and DMR's Center for Strategic Leadership. 1998. The Information Paradox: Realizing the Business Benefits of Information Technology. Toronto: McGraw-Hill,

Wilkinson, Margaret Ann, Terra Strong and Peter Mercer. 1996. Mentor, Mercenary or Melding: an Empirical Enquiry into the Role of the Lawyer. Loyola University Chicago Law Joumal 28(2): $373-418$.

Williams, David Ricardo. 1995. Just Lawyers: Seven Portraits. Toronto: Osgoode Society for Canadian Legal History 